\title{
AFRICAN, BLACK AND AIC THEOLOGIES AS THE MAIN HISTORICAL SOURCES OF CONSTRUCT FOR AN AFRICAN CHURCH
}

\author{
VS Molobi \\ Research Institute for Theology and Religion \\ University of South Africa
}

\begin{abstract}
This paper is attempting to engage a broader historical discourse by Mugambi in African Christian 'theologies' although, plurality of theology seem not to be his interest. In some instances this article tried to challenge some of his thoughts particularly on Black Theology. This might be regarded as notoriety, but it is merely intended to test his. African Theology, Black Theology and the AICs are the initiatives of the African scholarship. Many theologies emerged alongside African Theology, particularly in South Africa which may sometimes seemed to be challenging African Theology itself. Mugambi and some prominent African theologians seem to be somehow deterred by this and want Black Theology to take a back sit in favour of African Theology. Some African scholars are adamant that Black Theology is still relevant in places where racism has left its legacies which affect people badly even in a democratic South Africa. These three trends of theology seemed to be carrying vital weight which none of them its own can provide, therefore to me the issue of coexistence is crucial.
\end{abstract}

Key Words: African Theology, Black Theology, Inculturation, Contextualization and Liberation

\section{Introduction}

The past has shown that the battle to comprehend a theology that is African has many facets. Mobility of the global change has great impact on the theological catch-up programs intended for Africa today. There are number of factors that have traditionally hampered the theological catch-up in Africa and it was not new for those who were concern about the rediscovery of a new theology for Africa. Initiatives of theology of this nature have already being ventured into. The latest construction of such a theology was by Okoye (2006:1) who view African Theology as theology that was meant to reflect on the gospel, Christian tradition, and the total reality in an African manner and from the perspective of African world view. Okoye's (2006:1) opinion was that African Theology from cultural perspective sought to give African expression to Christian faith. He distinguished three currents of African Theology as: African Theology, Black Theology in South Africa and Liberation Theology. This was the part Mugambi was engaged in discussions relating to the interaction and relevance of the three historical trends in African scholarship.

Mugambi (1995) referred to his book "From liberation to reconstruction: African Theology after the cold war." This book was his turning point in theology for Africa because it came out of his long history and experience in Africa. The experience in this book unfolds from the geo-political history of 1960-1990's suggesting paradigm shift from 'liberation' to 'reconstruction.' To him reconstruction has occurred in the world where the national 
borders matters no more. ${ }^{1}$ He suggests that Africa's reconstruction has to come to terms with the emerging 'New Order.' ${ }^{2}$ And a corresponding theology had to emerge in a reconstructive, inclusive, complementary, integrative, programme driven, people centred, deedoriented, participatory, regenerative, future sensitive, cooperative and consultative. The opposite of all these factors ought to be rejected vehemently according to him. The descriptive, literature review and active dialogue remained significant for this discussion.

\section{Missiological and Theological Construct for an African Church}

Indeed Mugambi is not a Missiologist; however his prolific writings dispense a missiological necessity because of the depository information which in a long run cannot elude its significance of encouraging African Theology as heritage. This is well expounded in his other book entitled 'African heritage and contemporary Christianity' published in (2000). In it Mugambi expresses his thoughts of Western Christianity and African culture and how they were suppose to have encountered each other. Mugambi grounded his ideas by getting involved in areas of research occupying his mind world wide. His several visits to universities in South Africa as a guest professor, attending and participating in conferences reflect his serious engagement in areas of his passion. He wished to groom young scholars and academics to take from where he has left into the future.

Mugambi has organised workshops and seminars for various African age groups about church, ecology and theological challenges in Africa. Apart from his criticism and justifications of the existing African theological structures, he was also concern about the negative effects of the declining morals and economy in the continent. His book (2001) 'Christian theology and environmental responsibility' emphasised the reconstruction of mind towards sustainability of African environment as the heritage for future generations. From the same perspective, Maluleke (1996:3-19) has appealed within an inherited body of tradition, for the new ideas and realities, that will fulfil people's aspirations within their tradition, and alter the basis of their self-understanding within the same tradition. ${ }^{3}$ Mugambi emphasised a need for paradigm shift from the 'Old World Order' into the 'New World Order. ${ }^{4}$ This initiative was not individualistic but cooperative and communal. In this way Mugambi was not just a scholar but a mentor to many in the African continent and abroad. He wished to hear from the voices of many Africans who were being lifted to higher and better social levels.

\section{Connections in African Theology according to Mugambi}

African Theology, Black Theology and Theology of the AICs shared common vision on liberation, of an autonomous and truly African Church, a Christ who was at home among Africans, and vibrant and meaningful African culture (Molobi 2004:124). All these

\footnotetext{
Perhaps Mugambi is referring to the effect of free movement, with fewer restrictions at the border posts in Africa.

2 New World Order (Mugambi 2001:212-206) is referring to the end of "Cold war - five decades after the Second World War" which brought new priorities in international politics and economics.

4 Old and New World orders (Mugambi 2001:213-4) are referring to the inactiveness of the African Churches and Councils which changed their positions after the fall of communism in 1990 as though communism was their stumbling block. Their expectations from the university theological analysis may have led them compromise their public profile of the church. Also their dependence on the development funds from churches abroad let them be influenced in favour of adopting foreign theological guidelines.
} 
theologies were the initiatives of the African scholarship. They were intended to produce knowledge systems of God which will help to established culturally autonomous churches in their African context. His book (2000:88) 'African heritage and contemporary Christianity,' Mugambi referred to Christianity that is drawn by cultural effort to reach out communities of the world. And thus, concludes that Christianity in Africa came wearing the mask of the culture which were developed from the west.

The book titled "From liberation to reconstruction: African Christian theology after the Cold War," Mugambi (1995:258) clarified pointers towards his understanding of African Theology. Five hints resulting from his 'Liberation for reconstruction... ${ }^{5}$ were identified by Mowase (1997:909-11) as: (i) a theology of preservation, (ii) a theology that is critical to missionary enterprise, (iii) a theology that supersedes the ecumenical analysis and solutions towards the scandalous and competitive denominational posturing. (iv) Africa's place in the New World Order will have to provoke the rethinking of Pan-Africanism and the role of Organisation of African Unity. (v) Lastly, Mowase discovered that Mugambi was also referring to a reconstructive vision highlighting the agricultural policies stressing production of consumables than growing cash crops. The positive responses to these themes were to encourage a theology that can preserve the African heritage Mugambi is referring to.

Mugambi (1995:213) bemoans that African continent produces what it did not consume, and consumes what it did not produce. Moreover when he looked back into the 1960's where the concern was to eliminate poverty, disease and ignorance (Mugambi 2001:38). In macroeconomic terms, today the world is much richer than it was at the beginning of the twentieth century. But the gap between the affluent and the destitute is growing much wider today than it was before. ${ }^{6}$ This is not only a historical question on economics and politics but much more on ethics and theology. ${ }^{7}$ Mugambi seems to be suggesting that anyone who was seriously engaged in writing African Theology could not do so without addressing key themes like those Mowase (1997 has highlighted from Mugambi 1995s 'From liberation to reconstruction...').

One area which Mugambi seems to have missed as a necessary puzzle is the one which he is actually less enthusiastic and that was Black Theology. Africa as a big continent is faced with many challenges that need a resolve from this theological perspective as well. To create a single handed premise of argument in dealing with African crisis will seem to be unrealistic. There are other theologies which have emerged alongside the African Theology. Sometimes it may seem as if they are challenging African Theology itself, but they are necessary to address crisis as is perceived. The following part will focus on Black Theology and its contribution to African Theology as well.

\section{Some African Scholars Views on Black Theology}

Mugambi has joined the likes of Mbiti, Setiloane and Motlhabi ${ }^{8}$ among others who are viewing Black Theology as having no future since democracy in South Africa. Mbiti (1974) viewed Black Theology as a ready-made western theology turned into a consumption

5 These themes were well articulated in Isaac Mowase's review of Mugambi (1995) "From liberation to reconstruction: African Christian theology after the Cold War." In Journal of the American Academy of Religion, vol. 65. no.4, Thematic issue on "Teaching in Religion and Theology: (Winter. 1997)", pp. 909-911. Mugambi, op cit, 38.

Ibid, p. 38 .

These are well known theologians in faculties varying from systematic and ethic, practical theology and philosophy or religion in a person of Mbiti. 
commodity for Africans (Maluleke in tutorial letter MSB301-F/102:88). Setiloane (2001:59) saw African Theology and Black Theology as soul mates belonging to the same stable each with peculiar contribution to the struggle for liberation. African Theology should never, ${ }^{9}$ in spite of all taunts of failing to be 'prophetic' in the traumatic situation the black people found themselves in South Africa for example, cease to see its role as sending back the blacks to their grassroots.

On the same attitude Motlhabi (1994:113-141) recapped Mosala's emphasis on reappropriation ${ }^{10}$ of traditional religion by both African Theology and Black Theology. This has convinced him that Mosala supports him that Black Theology should be fused into African Theology. Motlhabi alleged that earlier Buthelezi's emphasis on Black Theology was more relevant for South Africa during the struggle for liberation than African Theology. Maluleke (1995:1-30) however, challenged this thought with his title 'Black Theology lives on permanent crisis' which shows disinclination towards giving up Black Theology at all costs. Black Theology for him is part of black consciousness and history of denying blacks during apartheid (civil) rights and degrading slang such as 'bantus,' 'kaffirs' and 'non-white.' 11 Some argue that Black Theology was the latecomer in South African circles of politics for it could be traced to some thirty years ago. During the times of unrest in South Africa, African Theology was exclusively concerned about issues of indigenization and Africanisation ${ }^{12}$ in the traditional sense (Motlhabi 1994:8). Blacks or 'African indigenous' were seeking answers directly relevant to their condition and problems or racism, landlessness, deprivation, poverty in the midst of plenty, and general suffering and oppression.

Finally, Motlhabi confirmed that African Theology came of age and this is where it is rendering Black Theology redundant (MSB 301/F/102:28-29). According Mugambi; Motlhabi; Mbiti; Setiloane and others, African Theology has been significantly rehabilitated and must continue to be rendered more responsive to all existential problems of African Christians. Mugambi advocate that Black Theology will never be a theology on its own without 'white theology' on the other side. The debate on Black Theology indeed is not near the end. Kritzinger (1989:236-240) identified areas that were crucial to be critically evaluated if Black Theology was to survive its demise in the next century. Issues of existentialism including guilt, despair, and illness 'witchcraft' and death need to be addressed. Others are context analysis, conversion, ecology and ideology. In expanding its horizon African Theology on the one hand may need to appreciate to be not the only contestant in the public discourse. Black Theology and theology of the AICs occupy certain permanent space and

\footnotetext{
Setiloane, op.cit, 59.

10 Mosala (1986:19) stated that: ... without re-appropriation (reoccupation) of traditional African religions and societies [sic] both African and black theologies will build their houses on sand. A Black Theology of liberation must draw its cultural hermeneutics of struggle from a critical reappropriation of black culture just as African Theology must arm itself with the political hermeneutics that arise from the contemporary social struggles of black people under apartheid capitalism.

11 Number of black organisations emerged in the 1960's like University Christian Movement (UCM), the Southern Africa Student Organisation (SASO) and some caucuses as the Black Priest Solidarity Group (BPSG) and St Peters Old Boys Association (SPOBA) among Roman Catholics, the Belydende Kring (BK), the Black Methodist Consultation and Interdenominational Association of African Ministers of Religion (IDAMASA) were some of the think tanks of the South African Black Theology (Maluleke in tutorial letter MSB301-F/102:89). The naming of the organisations that supported black consciousness in South Africa was to ensure firm solidarity for the integrity of blacks' lives.

12 See also Mugambi 2000 “African heritage and Contemporary Christianity" and Mugambi's (1998) "Jesus in African Christianity"- full details in bibliography.
} 
cannot easily be moved from where they are. It is therefore expected that the main African theological key players coalesce in addressing critical issues independently in Africa. What are these carrying for the church that is African? Perhaps Liberation, Ecclesiology, Christology and Enculturation perspectives can give a lime light.

\section{Four Theoretical Perspectives}

Liberation, Ecclesiology, Christology and Enculturation surfaced strongly in some of $\mathrm{Mu}-$ gambi's works and edited series but without neglecting their different historical contacts. A chapter on "ecumenical movement and the future of the church in Africa" Mugambi (1999:26) concludes that: "...unity among all churches is needed for the sake of the Church's mission in the world mission for reconciliation and liberation from all forces of greed and selfishness and prejudice that bring hatred and division to the world we live in." The described perspectives in this paragraph are aiming at the common purpose of supporting the indigenous church in Africa. We will look into perspectives separately.

\section{Liberation}

African Theology, Black Theology and theology of the AICs share understanding of Jesus as the liberator. In respect of his sermon in the synagogue in Nazareth (Lk 4:16-21) plays a key role (Molobi 2004:124). Jesus is seen as the one who frees men, women and children from satanic power, human sin, death and various forms of sickness. Humanity is therefore meant to enter the New Kingdom which Jesus came to inaugurate, one which is different from every kind of earthly structure or community. In this new community free women and men will be able to fulfil their role as children of the new kingdom (ibid). Although all these streams view Jesus as the liberator, in view of Luke 4 in the Bible their understanding does not suggest being completely similar in all respects. There are differences of emphasis and differences of understanding of specific terrains in human life where this liberation is at work (Molobi 2004:125). Such a comprehensive liberation requires full account to be taken into actual African situation (see Bujo in Molobi 2004:125). According to Bujo (ibid) African Theology makes a good theory in practice but not successful in breaking free from the university lecture halls and congresses. In my opinion African Theology elaborates on a theory which does not successfully help itself to be practical and useful to broader African society. As a result African Theology fail inspire confidence in Africans at grassroots level.

As for Black Theology in South Africa, it reflects the work of theologians who closely worked with Cabral's definition of liberation, adapted and applied in South Africa by Mosala (1989:67). For most Black theologians, liberation means liberation of the productive forces of a country. For this to take place all kind of imperialist or colonial domination must be liquidated, and every measure be taken to avoid new exploitation of the people. Only in this way can liberation consisting of equality and social justice and freedom, be established.

Mugambi (2001:211) affirmed this by pointing out that ecumenical movement of the early 70's in Africa has promoted the liberative type of Christianity. And this has made Christianity the target of attacks by fundamentalist crusaders. Mugambi found that from 1960's to 1970's the main struggle for liberation within the circles of churches was between the missionary personnel and the funding in Africa and elsewhere in the third worlds. This (Molobi 2004:126) is suggesting that both African Theology and the Black Theology do not succeed in rooting their good Liberation Theology in every practice because of their 
choice of interlocutors, while AICs practice and bring about liberation at the grassroots without a clear connection to the ecumenical theological understanding.

\section{Ecclesiology}

When Jesus declared to his followers that he would 'build' his ecclesia, it was not clear of what form or structure that ecclesia would take (Matt. 16:18). Christians in Jerusalem thought of a Judaic church, so that Gentile Christians would have to be 'Judaised' in order to become members. The first Council in Jerusalem rejected this interpretation (Waruta 1998:31). As a result, Greek, Latin and Coptic churches could grow, rooted in their own cultural soil. Africa is still striving for a truly African church, free, autonomous and rooted in Africa among Africans.

From the same context Waruta (1998:34) identified four major types of churches in African Christianity. He identifies firstly the 'dominant' types. These are churches with strong links to their metropolitan origins; they generally have historical 'state church' mentality. Examples of these types are the Roman Catholic, Anglican, Presbyterian and Lutheran churches. Secondly there are the 'popular' types (Waruta 1998:36) breaking or modify certain forms of the dominant types. In the third place there are the 'distinctive' types (ibid.) which are usually small churches, very effective in carrying out their mission almost wholly distinct to themselves. Many belong to historical groups such as the Mennonites, Quakers or Friends, Salvation Army, Seventh Day Adventist, and bigger faith churches such as African Inland Church and the Baptists. These churches tend to have their own distinctive traditions such as special uniforms, worship on Saturday (the Seventh Day Adventists) or baptism by immersion as in the Baptists. They hold as faithfully and intensively to their traditions as do the dominant types of churches. The fourth type is the 'indigenous' or 'independent' types (Waruta 1998:37). These types have adopted a traditionally African world view in which human events seem to be primarily controlled by spiritual forces. The urgent challenge is to adopt or suggest a suitable and committed form of African Church born of the African mind and Christian experience. Both the dominating church types and the popular types just cannot break the umbilical cords with the west. Then what and where is the African church? Mugambi had a point when demanding for a theology that is African and that can govern the African indigenous (italics mine) churches.

It is true then that African and Black Theology and the vibrant church practice (or theology of the AICs) can be melted together as complementary in creating an institution which is missionary by its very nature but being fully aware of its traditional and theological links to the churches universal (Molobi 2004:133). To alienate first converts of the church in Africa from their traditional homestead was a big mistake. All the three theological streams are aware of this and they are striving to correct it and it can be done when they belong together even though distinct from each other.

\section{Committed Form of African Church}

The church in modern African Christianity has to rely on the Africanization of Christianity in dialogue with the Christianization of Africa (Mugambi 1989). Perhaps a good starting point is the observation by Kanyandago (1998:179) relating to the disfigured body of Christ to African ecclesiology. He mentions; as cases of disfigurement the human suffering on the African continent which immeasurably needs urgent attention. Added to this is, the generalized economic backwardness and poverty, unemployment and hunger. On top of this the international trade is structured in such a way that it discriminates against products of the 
Third World (Saayman 2003:67-72). All of these factors are significant in ecclesiological formation and theological discourse in Africa. Christianizing Africa and Africanizing Christianity are therefore going to require all the best talents of trained theologians and laity in Africa. The problem that the local church is facing in Africa today is less communication between the theologians and lay preachers in the church. There is no active discourse between African Theology, Black Theology and the AIC, and this adversely affects the birth of a vision for mission in Africa in the twenty-first century.

The most aggrieving aspect of the ecclesiological body of Christ across all church types indicated above is the influence of a privileged and authoritarian historical background. This Christendom is not that of sharing in modesty and humility, but 'winning' and 'conquest' of other people, that of domination and absorption into ecclesiological hegemony rather than enhancing their spirituality and dignity (Waruta 1998:40). Can African Christian have the courage to transcend these hegemonies and recover a different spirituality which is akin to their more tolerant and unprivileged heritage? How can the dynamism of the Gospel be employed to create such spirituality in Africa? These questions are significant for a vision for mission of Church that is African. One dimension of a solution may be found in the tenacity and distinctiveness of AIC. It is because they are controlled by birth, death, health, harvest, road accidents, thunderstorms, political elections, as purposive act of spiritual powers (Barret et al.1973:xv).

Unlike the dominant, popular and distinctive Christian churches, indigenous churches do not experience the presence of God through documents or traditions but in the context of their community life and existential realities, with little external references validating their authority. Since AIC are theologically spontaneous, they give greater space for indigenous voices in the Africanization of Christianity. AIC can play a vital role in developing African Christianity, as is evidenced by the large numbers of new members they attract. One important dimension of AIC ecclesiology is their encouraging celebration of life in being the church (Nthamburi in Mugambi and Magesa 1998:53).

We can therefore (Molobi 2004:134) argue that the important contribution by the AICs will be to provide and outline the structures and relationships for living together as a truly African community of faith. African Theology and Black Theology can make contribution in terms of theological reflection on incarnating the gospel demonstratively and attractively, in such a way that it is recognized by the rest of the body of Christ as authentically Christian.

\section{Inculturation}

The social and religious struggle in Africa will be perpetual as long as there are poverty, homelessness, deprivation, disease, illiteracy and epidemics. This poses a challenge to African Christianity. In these circumstances African Theology, Black Theology and the AICs will have to deal first with foreign theological domination, and strive to pave a way for the coming into being of a free, autonomous and liberating African church. They have to be hungry for changing the lives of African Christians from ecclesiastic inferiority to self-confidence. The issue of identity is very important in Africa and several attempts have already been made to encourage Africans to take their African identity seriously.

Mugambi's (1989) work: African Heritage and contemporary Christianity is pleading for a process of Africanization in Christian belief and in the African church. Mugambi distinguishes between 'transformation' and 'replacement'. Throughout history Christianity worked to transform cultures and traditions through contextualization and inculturation. 
However, missionaries in Africa strove to replace African culture rather than transforming it. This has resulted into a church which was in most respects pale imitation of the European churches. African Christians need to break free from this monopoly by foreign missionary intellectuals in favor of a homegrown theological knowledge system. They must also be encouraged to appreciate themselves and utilize their capabilities. The achievements by scholars who study abroad were both good and bad for the African continent. They were good because they informed Africa about the international events and opportunities. On the other hand were bad when wanting to impose foreign ideas and concepts without the blessings of grass-roots Christians. Scholars who study abroad were often divorced for long periods of time from the communities they claimed to be representing. They therefore replace what they think is out of fashion with their personal interests, thus continuing the trend set by the missionaries.

\section{Christ the African: Inculturation and Contextualization}

Inculturation is one of the patterns in which 'pluriform' character of contemporary Christianity manifest itself (Bosch 1992:447). The original Christian faith never exists except as 'translated' into a culture (ibid). Christianity as a result is not supposed to be a burden to the people of culture, but an alternative towards solutions of their social problems. According to Anderson (1992:117) relating to Jesus as the ancestor, is marked by the concept spirit which remains vital in the African life. It is the source of healing sicknesses and deliverance from malevolence and capricious spirit world (ibid), which can be traced way back to time immemorial in Africa. These are not merely superstitions but real in African people's lives. Spirit in African understanding is the core of cultural existence and sustainability.

Since the down of Christianity, 'spirit' activity gained a public emphasis through biblical Christ. What makes the spirit unique is its continuum of the traditional religion, where it is essential for life to be always identified with the will of the spirit, at work and play, at worship, at a wedding perhaps, at meal times, in the harvesting and preparation of food (Anderson 1991:8-9). It is the deeper level of spiritual responsibility that leads into successful life. For an example the Pentecostal and Charismatic groups, the African Apostolic Churches and the Zionist Churches go deeper in their healing beliefs. They prophesy and speculate the cause of deceases. In the mainline churches on the other hand, although they pray for the sick, they will not commit themselves than suggesting that a sick person either consult a conventional doctor or a traditional healer. Perhaps we should view the African understanding of bible and culture in the next section.

\section{The Understanding of Bible and Culture}

The issue of biblical interpretation and understanding is crucial. Masoga (2001:146) is referring to the 'African organic readers' of the bible for example. To him the power of interpreting the bible is a two-way process. He is of the opinion that organic readers of the bible are produced by the periphery and advance to the centre to learn the ropes in the centre (ibid). They have a task to advance the periphery to become itself and not the copy cat of the centre. There is an ongoing relationship between organic readers and organic reading context. The ongoing agony itself offers growth, understanding and creativity, criticality, empowerment, and openness. This is the context which encourages the modelling of the African bible reading. This process can be realized by African, Black and AIC 
theologians revealing the true source of their theological reflections (James Cone in Masoga 20001:133). ${ }^{13}$

As a result of what has been indicated above, the three-step agenda for Inculturation in Africa would be: (i) African translations of the Bible, (ii) African interpretations of the Bible, and (iii) Formation of African Christian cultures, which include African Christian theological reflections. Granted that there is some circularity about the proposed procedure (since there can be no African translation without African Theology and Black Theology), it still gives us serious food for thought in a situation where many African cultures have no local Bible translations and an African biblical hermeneutic. Mugambi ${ }^{14}$ is of the view that we distinguish between African indigenous experience and that of the Africanists. ${ }^{15}$ In proper translation of the bible indigenous scholars must be given preference because they write from the core of their existence.

\section{Need to Change}

Inculturation is all about true reflection of a situation and the context in which is taking place. African Theology, Black Theology and the AICs are contextual theologies. They reveal how Christianity aught to have been done in the African soil. Kairos document appeal for Prophetic theology and shift from Church institutionalism (Der Walt in Speckman and Kaufman 2001:34). Prophetic Theology is referring to the moment of truth for liberation and freedom of expression in one's own language as well.

The reason for self encounter with the gospel is based upon the understanding of local theology not only as Christology, but also as pneumatology and ecclesiology (Bate 1994:108). Inculturation as a process guides the praxis of the Church in Africa as it sets up structures and institutions which allow it to be the church in the world responding to the joy and hope, grief and anguish of the men and women of our time especially those who are poor and are afflicted in any way (ibid). Mugambi has written a lot in this subject. ${ }^{16}$

13 Cone observed that often they tell us about the books that are similar and not so similar to their perspectives, but seldom do they tell us about the non intellectual factors that are decisive for arguments advanced on a particular issue.

14 Mugambi is a professor of philosophy and religious studies and former registrar Academic at the University of Nairobi. He distinguished between translation and transliteration which he regarded the latter as a problem for the Bible translation in Africa. To him translation of the Bible must be done from the understanding of indigenous communities.

15 'Africanists' are those Africans who write about Africans for interest sake and are not doing so from the core of Africans business. This goes with the fact that any person can translate the bible for Africans and may not take underlying issues seriously.

${ }^{16}$ These are few of Mugambi's selected works on inculturation: Mugambi, J., and Johannes A. Smit, editors. Text and Context in New Testament Hermeneutics. Nairobi, 2004.

- Mugambi, J and Magesa, L, (eds.) - Jesus in African Christianity: Diversity and Experimentation in Christology. Kenya Acton Publishers.

- Mugambi, J and Magesa, L, (eds.) - The Church in African Christianity: Innovative Essays in Ecclesiology. Kenya Acton Publishers.

- Mugambi, J and Wasike, AN (eds.) - Moral and Ethical Issues in African Christianity: Exploratory Essays in Moral Theology. Kenya Acton Publishers.

- Mugambi, J (ed.). The Church and the Reconstruction of Africa, Nairobi, AACC,1997.

- Mugambi, J (ed.). The Church and the Future of Africa Nairobi AACC 1997. 
Waliggo (in Mugambi 1998:8) argues that the permanence of Christianity will depend on the question as to whether it becomes truly African: whether Africans have made Christian ideas part of their own thinking, whether Africans feel that the Christian vision of life fulfils their Christian world views by becoming part of truly African aspirations. There are fears and suspicions in some African circles that African culture is bound to be the loser in the event of such a dialogue. Going from Africa's experience at the hands of some of its early and present day evangelizers, such fears may not be totally unfounded.

Adherents of African Traditional religions express the concern that accepting the Christian gospel would uproot Africans from their cultural roots and so make them less African. As a matter of fact (Ezeogu 1998:33) many Africans who have swallowed the westernized gospel of the missionaries line, hook and sinker, have indeed ended up like fish out of water, uprooted from their God-given cultures. The purpose of the gospel is to transforms people and cultures to bring the fruitful possibilities inherent in them. It must shed the light on the important concern of human existence and to their moral development and integrity (Gill 1981:144). The gospel should act as catalyst toward fuller development and the blossoming of people's innate potentials. What do they hope to gain from the gospel dialoguing with African cultures? Much, certainly, just as a seed that takes roots on new soil bears new fruit and thus perpetuates itself, so is the gospel that takes a root in the new culture to bear positive returns. Like the proverbial seed of wheat, unless gospel falls on rich soil of culture where it dies in that soil, it will fail to bear more fruits. Gospel should be interpreted into peoples' cultures through dialogue, so as people participate as well. African Theology, Black Theology and the AICs will live by hallucinations if this construct is not followed.

\section{Christ in Africa: Christology}

It is fair to state that biblical Christ was never set free by westerners to operate free in the African continent. He was dressed in Western robes, conceived of in terms of Western thought patterns, even represented in pictures and paintings as a typical white male. Christ therefore responded to some existential questions asked by Western people, but not to vital existential questions of Africans. Africans are in the first place looking for a Christ who will conquer for them the evil powers most feared by Africans: spirits, magic, disease and death (Nyamiti in Mugambi 1998:18).

The other important topics are Christ birth, baptism and death and they correspond to the rites of passage and life crises ritually stressed by Africans and incorporated in important rituals such as initiation rites. In fairness to the pioneering missionaries, they did try to indigenize their teaching about Christ as far as they found it possible. Some, for example, introduced him as the great Chief, intermediary between God and the people. In general, though, these attempts were superficial and often contradictory: it was mainly white missionaries trying to interpret Christ in terms of their understanding of African culture on behalf of Africans. The contradiction arose when many other missionaries taught that acceptance of Christ meant rejection of most African values. The process of Christianization thus boiled down to a process of Europeanization (Mugambi 2000:1-10). In many respects' Christ therefore continues to be experienced as foreign. For Christ to really 'come home' in Africa, African cultures and their self-esteem must be reconstructed as a living and vibrant reality, as worthy as any other human culture to incarnate Christ.

It is very important not to describe Africans as passive and helpless victims in the process of Christianization in Africa. They formed their own concepts and understanding of 
Jesus Christ despite missionary teaching. It is therefore no surprise that African theologians have already written and published a great deal of material on Christology. And in their spontaneous and enacted theologies AICs also have built up a Christology very different from the conventional missionary one. Therefore there is quite an amount of material on Christology in Africa already available, but a discourse to bring the various trends together and meld them into a Christ proudly at home in Africa has not yet begun. I think the following remarks can be valuable in starting such a debate. In the first place the 'white' Christ of the missionaries has to be replaced with Christ, the black man par excellence. I use the term black here not primarily in ethnic terms or in terms of skin pigmentation, but rather in the sense in which Black Theology uses the term in a socio-economic-political way. Christ is a black man because of his own poverty and class position, and because he identified completely with the miserable, the outcast and the disenfranchised. The creation of such a black Christ is very important for African self-esteem in relation to the rest of the world. Such a black Christ has indeed largely been constructed by the members of the AICs, without much theological reflection. Melting together this existent practical black Christ with the solid theological reflection done by African and black theologians will set the African church free.

\section{Conclusion}

African Theology, Black Theology and the AICs coexist; their initial growth and development rendered them to be autonomous (Molobi 2004:141). As a result there is little hope of dissolving them into one. Theology in Africa should become a force for liberation relating among others spiritual salvation and human liberation. Mugambi has raised many questions and gave guidance to upcoming African scholars to take the debate further. The refusal of reading African Theology, Black Theology and theology of the AICs is a sign of default somewhere down their line of history and that need to be revisited. In recent times there have been many Christological models that came through the 'pen' of African theologians. Christ is called the liberator, the ancestor, the first born son, the master of initiation, the healer, the African king, the African chief, the mediator, the saviour, the giver-of-life, the African lover, the all-powerful redeemer, etc. These areas need to be revisited by the theologians from the three streams to interpret and attach meaning to merge challenges of this dispensation.

Mijoka (2001:164-5) has indicated from his book on 'Preaching and the Bible in the African Churches,' that: The characteristics of African traditional concepts and terms are rarely used in the Christian Church in Africa. On the one side, the AICs preachers are silent to the question of whether they support or condemn African culture. Moral issues are not couched in African traditional terms. Although AICs are separate, they preach the same Gospel as in the mainline churches and on this note the AICs present nothing unique to the gospel. African, Black and AIC theologians must change indeed from becoming products of denominationalism and into open minded and pluralistic in approaching theology in Africa. This whole exercise is the responsibility of the African theologians of various stables in the continent.

Theology is a human construct as it is carried out by fallible human trying to make sense of God's revelation and our human experience (Molobi 2004:6). Therefore theology is always open to being subversive, thus three theological trends can become self-maximising rather than self-transcending. The focus should be making African Theology selftranscending so that it can have capability of changing African life for the better. Not everything is legitimate in theologies for all situations (ibid.). There are boundaries which 
from time to time need to be clarified; particularly when the Christian community is faced with unprecedented challenges of (e.g. agnosticism, clericalism, colonialism, racism and secularism). Of course the location of frontiers is open to debate and always fluctuating, for the Church ideally is always both reformed and always reforming. This is also discernable from Mugambi's insight of theology in Africa.

\section{BIBLIOGRAPHY}

Anderson, A 1991. Moya: The Holy Spirit in African Context. Pretoria: Unisa.

Anderson, A 1992. Bazalwane: African Pentecostal in context. Pretoria: Unisa.

Andria, S and Saayman, W 2003. Missiology and Ecclesiology a perspective from Africa: Missionalia 31:3, Nov 2003).

Barret, DB et al 1973. Kenya Churches Handbook: The development of Kenyan Christianity 1948-1973. Kenya: Kisumu Evangel Publishing House.

Bediako, K 1995:84. Christianity in Africa: The renewal of a Non Western Religion. Edinburgh: University Press, Mariknoll: Orbis.

Bosch, DJ 1992. Transforming Mission. New York, Orbis Books.

Ezeogu, EM 1998. International review of Mission. Vol. Lxxxvii No. 344.

Gill, JH 1981. On Knowing God. USA: Westminister.

Kanyandago, P 1998. 'The disfigured body of Christ' in Mugambi JNJ and Magesa L, (eds.). The Church in African Christianity. Nairobi, Kenya: Acton Publishers.

Kritzinger, JNJ 1989. Department of Missiology: Tutorial letter MSB301-F/102. Pretoria: Unisa.

Kritzinger, JNJ 1989. South African Black Theology: Missions as liberation. Third world theologies, Study Guide 2. Pretoria: Unisa.

Magesa, L and Nthamburi, Z 1999. Democracy and Reconciliation: A challenge for African Christianity. Nairobi, Kenya: Acton Publishers.

Maluleke, SM 1995. Black Theology lives!-on permanent crisis. Journal of Black Theology in South Africa 9:1 (May 1995) 1-30. Pretoria, Unisa.

Mbiti, J 1974. An African views American Black Theology. Worldview. 17:8 (August 1974) 41-44.

Mijoka, Hilary BP 2001. Preaching and the Bible in African Churches. Nairobi, Kenya: Acton Publishers.

Molobi, MS 2004. African Theology, Black Theology and the AICs: A vision for mission. Unpublished Thesis. Pretoria; Unisa.

Mosala, I 1989. Biblical Hermeneutics and Black Theology. United States: Eerdmans.

Motlhabi, MBG 1994. African Theology or Black Theology? Towards an integral African Theology. Journal of Black Theology in South Africa 8:2 (Nov 1994) 113-141.

Mowase, IMT 1997. From liberation to reconstruction: African Christian theology after the Cold War. Review in Journal of the American Academy of Religion, vol. 65:4, 909-911.

Mugambi, JNK 1989. African Heritage and contemporary Christianity. Nairobi, Kenya: Acton Publishers. 
Mugambi, JNK and Magesa, L 1998. The church in African Christianity. Nairobi, Kenya: Acton Publishers.

Mugambi, JNK 1995. From liberation to reconstruction: African Christian theology after the Cold War. Nairobi: English Press.

Mugambi, JNK \& Magesa L (eds.) 1998. Jesus in African Christianity. Nairobi, Kenya: Acton Publishers.

Mugambi, JNK 2000. Jesus in African Christianity. Nairobi, Kenya: Acton Publishers.

Mugambi, JNK 1996. African Churches in Social Transformation. Journal of International Affairs, 50:1. pp. 213-214.

Okoye, JC 2006. African Theology. www.uni-tuebingen.

Saayman, W 2000. Missionary by its very nature. Missionalia 28:1, April 2000.

Speckman, MT \& Kaufman, LT 2001. Towards an Agenda for Contextual theology. Pietermaritzburg: Cluster Publications. 